This article was published in Applied Catalysis B: Environmental, 146, 192-200, 2014

http:// dx.doi.org/10.1016/j.apcatb.2013.04.028

\title{
Azo-dye orange II degradation by the heterogeneous Fenton- like process using a zeolite Y-Fe catalyst - Kinetics with a model based on the Fermi's equation
}

Maryin L. Rachea,* , Andrés R. García a , Hugo R. Zea a , Adrián M.T. Silva b,

Luis M. Madeirac, Jose H. Ramírez ${ }^{\mathrm{a}}$

a Departamento de Ingeniería Química y Ambiental, Facultad de Ingeniería, Universidad Nacional de Colombia, Carrera 30 Numero 45-03, Edificio 412, of. 201, Bogotá, Colombia

b LCM - Laboratory of Catalysis and Materials - Associate Laboratory LSRE/LCM, Faculdade de Engenharia, Universidade do Porto, Rua Dr. Roberto Frias $s / n, 4200-465$, Porto, Portugal

C Laboratório de Engenharia de Processos, Ambiente e Energia (LEPAE), Departamento de Engenharia Química, Faculdade de Engenharia, Universidade do Porto, Rua Dr. Roberto Frias s/n, 4200-465, Porto, Portugal

\footnotetext{
Abstract

The degradation of Orange II dye (OII) by a heterogeneous Fenton-like process was studied using a catalyst with $5 \mathrm{wt}$ \% of iron after ion-exchange in a Na-Y zeolite support. The catalyst was characterized by $X$ - ray diffraction (XRD), N2 adsorption, atomic absorption spectroscopy and X-ray fluorescence (XRF). The effect of the initial concentrations of $\mathrm{H} 2 \mathrm{O} 2$ and $\mathrm{OII}, \mathrm{pH}$ and temperature on the degradation rate of OII was investigated by carrying out experiments in a batch reactor. The OII concentration histories (i.e., concentration evolution along reaction time) were described by a simple semi-empirical kinetic model, based on the Fermi's equation, which captures simultaneously the influence of all the reaction conditions with a few adjustable parameters. The adherence of the model to the data was remarkable, and the effect of the operating conditions on the obtained fitting parameters - apparent rate constant and transition time was analyzed.
} 


\section{Introduction}

The domestic and industrial activities generate large amounts of residual wastewater, whose direct disposal to natural courses causes a considerable effect in the environment. This fact, together with the need for water reuse, makes essential to develop proper technologies for wastewater treatment in order to achieve the desired level of water quality. The textile industry is an example of the industrial sector where fresh water is often used indiscriminately in large amounts, mainly as a solvent. Dyes are also very common in textile processing, several thousands of different dyes being manufactured worldwide due to the many different types of products to which dyes are applied as well as to the different conditions of service for which dyes are required [1]. Among the dyes available on the market today, up to $70 \%$ are azo compounds [2]. Orange II (OII), also called acid orange 7 , is an azo dye widely used in the dyeing of textiles, food, and cosmetics and, thus, OII is found in the wastewaters of many related industries [3] because of the high rejection levels of dyes by these products, namely by fibers. For these reasons, OII degradation in water has been studied widely [3,4].

Physical, biological and chemical treatments have been used for wastewater treatment. Flocculation, sedimentation, flotation, filtration, extraction and adsorption are typical physical or physicochemical operations. However, these processes may be costly, inefficient and often produce a high amount of secondary wastes. Ozone and hypochlorite oxidations are efficient decolorizing methods, but they are not so efficient to remove the overall organic content of the wastewaters, the equipment and operating costs are also high and a secondary pollution arises from the residual chlorine [5].

Recent progress in the removal of organics from wastewaters has led to the development of advanced oxidation processes (AOPs), which are in short based in the generation of extremely reactive species like hydroxyl and perhydroxyl radicals $\left(\mathrm{HO}^{\circ}\right.$ and $\mathrm{HO}_{2}{ }^{\circ}$, respectively). Among them, the oxidation using Fenton's reagent has proved to be a promising and attractive treatment method for the effective decolorization and degradation of dyes, as well as for the destruction of a large number of hazardous organic pollutants [5-8]. Besides, the process is simple and non-expensive, taking place at low temperatures and atmospheric pressure [9]. The homogeneous Fenton and Fenton-like processes involve the reaction of hydrogen peroxide with ferrous $\left(\mathrm{Fe}^{2+}\right)$ and with ferric $\left(\mathrm{Fe}^{3+}\right)$ ion, respectively [10].

The Fenton's process is used to treat industrial wastewaters [11], but the main drawbacks are mainly related with the formation of iron-containing sludges and/or the need for recovering the iron catalyst after the treatment. This 
shortcoming can be overcome in principle by developing heterogeneous Fentontype catalysts, and numerous attempts can be found that include incorporation of Fe ions or Fe oxides into porous supports. The corresponding mechanism, which is also quite complex as is the homogeneous one, can in this case be in short described by the following equations, where $X$ represents the surface of the catalyst wherein the iron species are anchored to [12]:

$$
\begin{aligned}
& X-\mathrm{Fe}^{3+}+\mathrm{H}_{2} \mathrm{O} 2 \rightarrow X-\mathrm{Fe}^{2+}+\mathrm{HO}^{\bullet}+\mathrm{H}^{+} \\
& X-\mathrm{Fe}^{2+}+\mathrm{H}_{2} \mathrm{O} 2 \rightarrow X-\mathrm{Fe}^{3+}+\mathrm{OH}^{-}+\mathrm{HO}^{\bullet}
\end{aligned}
$$

Zeolites [13-17], carbon materials [18,19], mesoporous and mixed oxides $[20,21]$ and clays [12,22-26] have been used as sup- ports of iron in the preparation of heterogeneous catalytic systems. In particular, zeolites containing transition metal ions have been shown to be promising solid-phase catalysts in the oxidation of a series of organic pollutants with hydrogen peroxide [27]. In addition, some authors have reported that heterogeneous zeolite-based Fe catalysts could provide similar catalytic activities as homogeneous Fe ions [28].

In this work, the heterogeneous Fenton's reaction has been carried out using Fe as active phase, supported on a $\mathrm{Y}$ zeolite. The influence of some of the main operating parameters, such as temperature, $\mathrm{pH}, \mathrm{H} 2 \mathrm{O} 2$ and dye concentration on the azo-dye Orange II degradation has been studied. A kinetic model (based on the Fermi's equation), recently proposed for saponite-based catalysts in wet hydrogen peroxide oxidation [29], was herein extended for the first time to zeolitebased catalysts. Such a model was developed aiming to describe, with a single function, the transient dye concentration data in this complex process. No similar models were found in the literature for such system. Upon validation, by comparison with experimental data, these models could provide a powerful tool for predicting the process performance under selected ranges of the operating conditions.

\section{Materials and methods}

\subsection{Catalysts preparation and characterization}

Zeolite $\mathrm{Y}$ containing high sodium weight percentage (5\%) was provided by the Heterogeneous Catalysis Laboratory of the National University of Colombia, where it was prepared in agreement with the experimental procedure proposed by Ostos Ortiz [30]. This material was subjected to an ion-exchange procedure with ferric chloride hexahydrate ( $\mathrm{FeCl} 36 \mathrm{H} 2 \mathrm{O}$ - Merck) treatment in order to replace the sodium from the zeolite. This treatment was carried out in beakers of $0.6 \mathrm{~L}$ of 
capacity, under controlled temperature $\left(20^{\circ} \mathrm{C}\right)$ and continuous stirring. For that, $0.25 \mathrm{~L}$ of $\mathrm{FeCl}_{3} 6 \mathrm{H} 2 \mathrm{O}$ solutions with different concentrations and $0.5 \mathrm{~g}$ of zeolite were mixed and maintained under constant stirring and controlled temperature; samples of the exchanged zeolite were taken from the ion exchanging solution, vacuum filtered and taken to an oven for drying at $110{ }^{\circ} \mathrm{C}$ overnight. The $\mathrm{Fe}^{3+}$ content was determined after $0.5 \mathrm{~h}, 1.0 \mathrm{~h}, 2.0 \mathrm{~h}, 2.5 \mathrm{~h}$ and $3.0 \mathrm{~h}$ of treatment. Ion exchange experiments were performed at three different values of $\mathrm{Fe} / \mathrm{Na}$ atomic ratios: 1,2 and 4 .

Chemical composition of exchanged and non-exchanged zeolites was obtained using X-ray fluorescence spectroscopy (XRF, Magix Pro PW - Philips apparatus equipped with a rhodium tube of $4 \mathrm{~kW}$ of maximum power) and atomic absorption spectroscopy (AAS, Thermo Scientific iCE 3000 unit). Samples were also analyzed by X-ray diffraction (XRD) using a P analytical X'Pert PRO MPD diffractometer. BET surface area was determined from the nitro- gen adsorption isotherms obtained at $196{ }^{\circ} \mathrm{C}$ in a Quantachrome Coulter apparatus.

\subsection{Catalytic experiments}

Catalytic experiments were performed in a jacketed $1 \mathrm{~L}$ batch reactor. The reaction temperature was controlled $\left( \pm 0.1^{\circ} \mathrm{C}\right)$ with a Poly Science thermostatic bath, Model 9510, and the $\mathrm{pH}$ was measured with an Orion $\mathrm{pH}$ meter, model SA520. In a typical run, the reactor was loaded with $0.25 \mathrm{~L}$ of an OII solution of known concentration (OII from Fluka), and both temperature and $\mathrm{pH}$ were then adjusted to the desired values under continuous stirring of the OII solution (which has a natural $\mathrm{pH}$ of 6.0 - for a $0.1 \mathrm{mM}$ concentration). The beginning of the reaction $(t=0)$ was considered when the catalyst and $\mathrm{H}_{2} \mathrm{O} 2$ (30 wt. \%, from Merck) were added together. Samples were withdrawn from the reactor at several times, filtered and reaction was stopped by adding excess $\mathrm{Na}_{2} \mathrm{SO} 3$ (from Merck), which instantaneously consumes the remaining hydrogen peroxide. A UV-vis Spectrophotometer (model Genesys 20, from Thermo Scientific) was used to follow the OII concentration histories, i.e., concentration evolution along reaction time, at $\lambda \max =486 \mathrm{~nm}$ (characteristic wavelength of the dye). The total organic carbon (TOC) was measured by catalytic oxidation followed by IR spectrometry for $\mathrm{CO} 2$ quantification using a SKALAR Formacs HT/Analyzer instrument, which has an automatic sample injector. In what concerns the iron leaching from the support, it was quantified by atomic absorption using a Thermo Electron Corporation spectrometer.

In this work, OII concentrations between 0.03 and $0.15 \mathrm{mM}$ were used 
(corresponding to total organic carbon contents in the range of 5.76-28.8 $\mathrm{mg}$ $\mathrm{L}^{-1}$ ), which are in the range of typical OII concentrations found in industrial effluents (between 10 and $50 \mathrm{mg} \mathrm{L}^{-1}$ ) [31].

Table 1 summarizes the conditions of all experiments per-formed. Several runs were conducted by varying the temperature (in the range $30-75^{\circ} \mathrm{C}$ ), the initial concentration of the dye (between $3.0 \times 10^{-5}$ and $1.5 \times 10^{-4} \mathrm{M}$ ), the initial $\mathrm{pH}$ (2-4) and the $\mathrm{H} 2 \mathrm{O} 2$ dosage $\left(6.0 \times 10^{-3}\right.$ to $\left.1.0 \times 10^{-2} \mathrm{M}\right)$. In such experiments the catalyst dose (load of Fe-zeolite in the batch reactor) was always $200 \mathrm{mg} \mathrm{L}^{-1}$. Some experiments were repeated at least twice and the average absolute deviation between repeated runs was always less than $5 \%$.

\section{Results and discussion}

\subsection{Catalyst characterization}

Fig. 1 shows the profiles of iron content in the exchanged zeolite as a function of time and atomic $\mathrm{Fe} / \mathrm{Na}$ ratio. It is evident that, for all $\mathrm{Fe} / \mathrm{Na}$ ratios, there is an initial fast increment of the iron content in the zeolite (in ca. $0.5-1 \mathrm{~h}$ ), becoming the iron content loaded practically constant afterwards and up to three hours regardless the atomic ratio of $\mathrm{Fe} / \mathrm{Na}$ tested - i.e., equilibrium has been reached. Increasing the value of the $\mathrm{Fe} / \mathrm{Na}$ ratio increases the amount of iron exchanged, the highest iron content of nearly $5 \mathrm{wt}$.\% being obtained when a $\mathrm{Fe} / \mathrm{Na}$ ratio of 4 is used (profile a in Fig. 1, yielding a final load of $4.8 \mathrm{wt}$ \% of Fe). For the Fe/ Na ratios 1 and 2 , the final iron contents obtained are 2.6 and $3.8 \mathrm{wt} \%$, respectively (profiles c and b in Fig. 1, respectively).

In the rest of this work, the sample with the highest amount of iron will be characterized in further detail and afterwards used in the catalytic tests.

$X$-ray fluorescence (XRF) results of the non-exchanged and exchanged zeolites, the last prepared using the stoichiometric Fe/ Na ratio of 4, are summarized in Table2. Before theion exchange process the non-exchanged zeolite does not show the presence of iron in its composition, as expected, but after the treatment with $\mathrm{FeCl} 3$ it is observed that ferric oxide concentration increases to $7.85 \%$, which corresponds to ca. $5 \%$ of iron content; based on the iron loaded in the solution and the amount present in the exchanged zeolite (cf. Table 2), an exchange yield of nearly $20 \mathrm{wt}$. \% was reached. In addition, the $\mathrm{SiO} 2 / \mathrm{Al} 2 \mathrm{O} 3$ weight ratios for the non- exchanged and exchanged zeolites are 3.45 and 3.71, respectively, which are 
close to the value reported for zeolite type $\mathrm{Y}(\mathrm{SiO} 2 / \mathrm{Al} 2 \mathrm{O} 3$ of 3.5) [32-34], while $\mathrm{MgO}$ and Co probably appear from the ferric chloride precursor.

The XRD patterns of the non-exchanged and exchanged zeolites are shown in Fig. 2 (profiles a and $b$, respectively). The XRD pro- files show that the crystalline structure of the zeolite changed after ion exchange, i.e. a loss of crystallinity is observed after the ion exchange process, some authors relating this loss of crystallinity to the effect of the charge on the ion-exchanging cation in the zeolite structure [35,36]. The XRD pattern of the non-exchanged zeolite allows to calculate a unit cell size of $24.50 \AA$ using an idealized cell cubic Fd $3 \mathrm{~m}$ (Faujasite). The XRD pattern of the exchanged zeolite shows a displacement to higher $\mathrm{d}$ values when compared with the non-exchanged zeolite-upon this new profile the unit cell size calculated was $25.05 \AA$; this observation is in agreement with the typical cell enlargement observed when materials with big ionic radii $(0.68 \AA)$ are incorporated into the zeolitic crystal structure. In addition, XRD profile of the exchanged zeolite contains peaks of iron oxide structures (corresponding to hematite) that are not identified in the non-exchanged zeolite. XRD profiles were analyzed using Jade 5 Software (from MDI, Inc.) and compared against ICDD PDF2 database. According to PDF\#97-009-6074, the main peaks

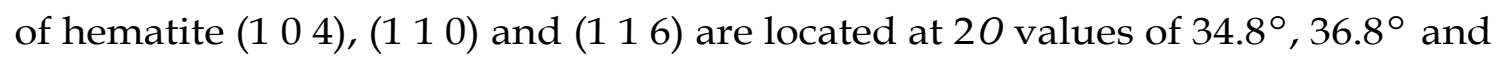
$56.8^{\circ}$, with an intensity of $100 \%, 66.3 \%$ and $45.6 \%$, respectively. The experimental XRD profile of the exchanged zeolite present three distinctive peaks at $34.9^{\circ}$, $36.9^{\circ}$ and $56.9^{\circ}$; the intensity percentage calculated having as reference the $34.9^{\circ}$ peak are $100 \%, 73 \%$, and $52.3 \%$; with a minimum intensity to background ratio of 8.6, the adjustment of these three peaks to the hematite profile is in the order of $0.86+0.05$. On the other hand the non exchanged zeolite presents a peak at $34.9^{\circ}$ but it lacks any distinguishable peaks around the $36.8^{\circ}$ and $56.8^{\circ} 2 O$ values. The combination of the analysis obtained calculating the unit cell and performing the hematite profile adjustment indicates that some of the exchanged iron was incorporated into the zeolite crystal structure and some other formed hematite crystals; however, it is difficult from the data collected to determine a quantitative distribution of iron.

$\mathrm{N} 2$ adsorption isotherm at $77 \mathrm{~K}$ of non-exchanged sample (see Fig. 3a) indicates that this material has a combination of micropores and mesopores, however after the ion exchange the volume of $\mathrm{N} 2$ adsorbed at low values of $P / P 0$ decreased, suggesting a reduction in the available microporosity. The determined pore volume and BET surface area after the ion exchange process decreased from 0.24 to $0.10 \mathrm{~cm}^{3} / \mathrm{g}$ and from 432 to $259 \mathrm{~m}^{2} / \mathrm{g}$, respectively. Therefore, properties like 
surface area and pore volume seem to be greatly affected by the ion exchange process, which is consistent with the decrease of crystallinity of the exchanged zeolite [37].

\subsection{Catalytic activity}

Adsorption experiments were first carried out, i.e. without adding the oxidant (hydrogen peroxide), using either the unchanged or ion-exchanged zeolite with ca. 5 wt. \% of iron. As shown in Fig. 4, OII removal from theliquid was very low and similar for both samples, approximately $6 \%$. Experiments were also carried out at different temperatures and $\mathrm{pH}$ values (within the ranges of the catalytic study cf. Table 1), but it was concluded that the effect of such variables in the adsorption process with the zeolite is almost negligible. Besides, it should be also referred that the OII oxidation by using $\mathrm{H}_{2} \mathrm{O}_{2}$ without any catalyst is practically negligible as compared to the catalytic process (ca. $5 \%$ after $4 \mathrm{~h}$ of reaction at $30^{\circ} \mathrm{C}$ and $6 \mathrm{mM}$ of oxidant) [31]; the same was verified for the ranges of conditions employed in this work.

The ion-exchanged zeolite material with the iron content of nearly $5 \mathrm{wt} . \%$ was then used as catalyst for the heterogeneous Fenton-like degradation of OII under different operating conditions. In the following sections, the effect of each parameter on the OII concentration histories is analyzed while keeping constant the other operating conditions, as described in Table 1.

\subsubsection{Effect of the temperature}

The OII concentration histories normalized by the initial concentration, $\mathrm{CO}$, are shown in Fig. 5 at four different temperatures (30, 45, 60 and $\left.75^{\circ} \mathrm{C}\right)$. It is evident that the oxidation reaction accelerates when increasing the temperature, which was expected due to the exponential dependency of the kinetic constants (for either radicals generation or their attack to the dye molecules) with the temperature (Arrhenius law). Nevertheless, the final OII concentrations, after 2 $\mathrm{h}$ of oxidation, are null whatever the reaction temperature in the range $30-75{ }^{\circ} \mathrm{C}$. Similar results were observed during catalytic wet peroxide oxidation of orange II over Fe-containing clays [31].

Fig. 6 shows the results obtained for the total organic carbon (TOC) removal, at two different temperatures $\left(30\right.$ and $45^{\circ} \mathrm{C}$ ), at constant $\mathrm{pH}$ of 3 . As expected, the oxidation reaction in terms of TOC degradation accelerates when increasing the temperature as observed for OII (Fig. 5); OII was completely degraded after 1.5-2 h of reaction regardless the reaction temperature used, while there is a fraction of 
TOC remaining in the solution even at the end of the experiments, corresponding to 53.8 and $31.8 \%$ of the initial TOC content for 30 and $45^{\circ} \mathrm{C}$, respectively (Fig. 6).

The performances of OII removal achieved at $30{ }^{\circ} \mathrm{C}$ might be considered satisfactory, although the process is not as fast as at higher temperatures. For industrial application, temperature could be increased to improve the process performance; in some particular cases this is even not necessary, because textile effluents have in some industries very high temperatures. However, taking into account that in most of the applications a lower temperature might reduce the process costs as well as possible leaching of the active phase, $30^{\circ} \mathrm{C}$ was the temperature chosen to carry out the following runs, where the other parameters were changed. Besides, this is closer to the temperature of reference in most studies (ca. $\left.25-30^{\circ} \mathrm{C}\right)$.

\subsubsection{Effect of the initial $p H$}

The influence of initial $\mathrm{pH}$ on the OII degradation was studied in the range of 2-4; an additional run was also done at $\mathrm{pH}$. Fig. 7 shows that when the initial $\mathrm{pH}$ increases from 2 to 3 the OII degradation rate quickly increases, decreasing drastically when the $\mathrm{pH}$ is raised from 3 to 4 . This behavior was observed in our previous studies with saponite-based catalysts [31], and agrees with literature findings, as it is usually accepted that acidic $\mathrm{pH}$ levels near 3 are usually optimum for Fenton and Fenton-like processes. Among other reasons, one can remark that increasing the initial $\mathrm{pH}$ for values higher than 3, the stability of the hydrogen peroxide decreases. Besides, at $\mathrm{pH} 2$ the generation of hydroxyl radicals decreases, since the hydrogen peroxide forms the hydroperoxonium ion $\left(\mathrm{H} 3 \mathrm{O} 2^{+}\right)$by proton solvation, and therefore does not react with $\mathrm{Fe}^{2+}$. It must be stressed that another experiment, performed at $\mathrm{pH} \mathrm{7,} \mathrm{led} \mathrm{to} \mathrm{a} \mathrm{negligible} \mathrm{OII} \mathrm{degradation} \mathrm{(cf.} \mathrm{Fig.} \mathrm{7).} \mathrm{In}$ addition, Fig. 6 shows the results obtained for the TOC removal at two different $\mathrm{pHs}$ ( 2 and 3 , keeping the temperature constant at $30^{\circ} \mathrm{C}$ ), illustrating typical results for the effect of the $\mathrm{pH}$, i.e., it is found that the TOC removal increases with the initial $\mathrm{pH}$ of the solution (from 2 to 3 ).

For a practical implementation of a heterogeneous catalytic system, it is crucial to evaluate the stability of the catalysts. For that purpose, a sample that shows a low iron leaching, but presenting simultaneously good catalytic performance, should be selected. With that goal in mind, three experiments were performed where two important variables on iron leaching were analyzed, temperature and $\mathrm{pH}$. In Fig. 8 one can see that iron leaching for $\mathrm{pH} 3$ is smaller at $30^{\circ} \mathrm{C}$ than at $45^{\circ} \mathrm{C}$, although in both cases is not very significant (always lower than $0.5 \mathrm{mg}$ 
$\mathrm{L}^{-1}$ ), the iron in solution being practically constant after $1.5 \mathrm{~h}$ of reaction.

The same figure shows the effect of the reaction $\mathrm{pH}$ on the iron leaching. It is clear that iron lost is more significant at $\mathrm{pH} 2$. There- fore, for long-term stability, it would be preferable to work at $\mathrm{pH} 3$ and $30^{\circ} \mathrm{C}$. Feng et al. [38] also found that iron leaching was much more significant at $\mathrm{pH}$ around 2. The Fe leaching at this low initial solution $\mathrm{pH}$ can be attributed to the dissolution of iron oxide at very acidic conditions. In a previous work of our group it was found a similar effect in terms of temperature and $\mathrm{pH}$ on iron leaching [12].

Therefore, for the conditions of reference in the Fenton's process of $30^{\circ} \mathrm{C}$ and $\mathrm{pH}$ 3 , iron leached out from the zeolite is below $2.1 \%$, putting into evidence that the process is essentially heterogeneous (not homogeneous). Besides, it also indicates the integrity of the zeolite, and the fact of being quite stable and reusable.

Taking into account that far better results were obtained at $\mathrm{pH} 3$, it was the value chosen to carry out the following runs.

\subsubsection{Effect of the initial $\mathrm{H}_{2} \mathrm{O} 2$ concentration}

As shown in Table 1, the initial dosage of $\mathrm{H}_{2} \mathrm{O} 2$ was varied between 6.0 and 10 $\mathrm{mM}$, for an initial dye concentration of $0.1 \mathrm{mM}$. Theoretically, $42 \mathrm{~mol}$ of $\mathrm{H}_{2} \mathrm{O} 2$ are needed to completely degrade $1 \mathrm{~mol}$ of the dye $(\mathrm{C} 16 \mathrm{H} 11 \mathrm{~N} 2 \mathrm{NaO} 4 \mathrm{~S}+42 \mathrm{H} 2 \mathrm{O} 2$ $\rightarrow 16 \mathrm{CO} 2+46 \mathrm{H} 2 \mathrm{O}+2 \mathrm{HNO} 3+\mathrm{NaHSO} 4)$ [38]. Therefore, the doses employed correspond to values above the stoichiometric amount for complete mineralization (which should yield a ratio of 1); ratios employed are in the range 1.43-2.38.

The effect of the initial hydrogen peroxide concentration on the dye degradation can be observed in Fig. 9. The results show that when the hydrogen peroxide load is changed from 6 to $10 \mathrm{mM}$, although differences between dye concentration histories exist, they are small. OII degradation obtained after 90 min is practically complete whatever the initial hydrogen peroxide concentration used. In terms of TOC removal, when changing the hydrogen peroxide concentration from 6 to $10 \mathrm{mM}$, the differences observed were practically null (data no shown). So, the minimum dose tested of $6 \mathrm{mM}$ was the value chosen to carry out the following runs.

\subsubsection{Effect of the initial dye concentration}

It is also of practical interest to investigate the effect of the initial pollutant concentration, as it is of importance in any process of wastewater treatment. As shown in Table 1, the initial dosage of OII was varied between 0.03 and $0.15 \mathrm{mM}$, 
for an initial $\mathrm{H} 2 \mathrm{O} 2$ concentration of $6 \mathrm{mM}$. Oxidant/dye ratios employed are in the range $0.95-4.76$ and correspond to values below and above the stoichiometric amount for complete dye mineralization (which should yield a ratio of 1 - cf. Section 3.2.3). Fig. 10 shows the concentration histories normalized by the initial dye concentration. The initial OII concentration showed a negative effect on its decolorization, i.e., the higher the initial dye concentration, the higher was the time required to degrade it completely (Fig. 10). The reported negative effect at higher OII concentrations results from the fact that for smaller dye concentrations, the molar ratio oxidant/parent organic compound is higher (because the amount of hydrogen per- oxide molecules initially present in the reactor is the same). The same inhibiting effect of the organic initial concentration on the oxidation performance was observed by several authors $[39,40]$.

\subsection{Kinetic model}

Mathematical models allow reactor design, scale-up and also to predict their performance. In fact, kinetic models obtained at laboratorial scale are crucial for further development of catalytic reactors. Recently, we have developed a kinetic model based on Fermi's function (the mirror image of the logistic function), Eq. (3), that has associated only a few adjustable parameters with intuitive meaning [29]:

$$
\frac{C}{C_{0}}=\frac{1}{1+\exp \left[k\left(t-t^{*}\right)\right]}
$$

In this equation, $k$ represents the apparent rate constant, including the catalyst dosage, and $t^{*}$ is the so-called transition time, related with the inflection point of the pollutant concentration curve.

The model was used to describe the effect of the main reaction conditions on the treatment of Orange II by the heterogeneous catalytic wet hydrogen peroxide oxidation (CWHPO) process using as catalyst a pillared saponite clay impregnated with Fe(II) acetylacetonate [29] and was never applied to the process catalyzed by other materials, including zeolites. The developed model is truly useful because with a single semi-empirical function (mathematical simplicity) it is possible to simultaneously describe the initial slow degradation of the pollutant (induction period) and subsequent rapid concentration decay (as also observed in Figs. 5, 7,9 and 10), a behavior that has been often observed for several oxidation reactions in AOPs. Therefore, this model allows to account for the pollutant concentration in the transition regime existing between both periods 
(inverse S-shape profile), and for the non-linear behavior observed during the induction period, in contrast with the commonly employed two-step pseudofirst-order model where two subjective separated linear regressions in semilogarithmic scale are used to describe the two different stages of the process [41]. The model, Eq. (3), was fitted to the normalized OII concentration histories $(C / C 0)$ obtained under different operating conditions, using the Marquardt-Levenberg algorithm that seeks the values of the parameters that minimize the sum of the squared differences between observed and predicted values of the dependent variable (the tolerance was fixed at $1 \times 10^{-10}$ ). Figs. 5, 7, 9 and 10 show the fittings for different temperatures, initial solution $\mathrm{pH}, \mathrm{H}_{2} \mathrm{O} 2$ concentration and OII concentration, respectively; the respective model parameters that were obtained after regression $\left(k\right.$ and $\left.t^{*}\right)$ are shown in Table 1 . The coefficients of variation $(k \mathrm{CV}$ and $\left.t \mathrm{CV}^{*}\right)$, expressed as a percentage $(\mathrm{CV}(\%)=$ standard error $\times 100 /$ parameter value), are also provided in Table 1. In general, the fitting of the model presented in Figs. 5, 7, 9 and 10, as well as the respective $k \mathrm{CV} \quad(1.2-5.9 \%), t \mathrm{CV}^{*}(1.4-5.9 \%)$ and $r^{2}$ (0.9930-0.9990) shown in Table 1, demonstrate the very good agreement of the model to all experimental data.

The apparent kinetic constant markedly increases with the temperature, $k=5.83$, 19.8, 37.0 and $56.4 \mathrm{~h}^{-1}$ at $30,45,60$ and $75{ }^{\circ} \mathrm{C}$, respectively, describing an Arrhenius behavior, as shown in Fig. 11a, and resulting in an apparent activation energy of $44 \mathrm{~kJ} \mathrm{~mol}^{-1}$ (cf.Table 1), which is only slightly lower than the value observed in previous publications with OII and other catalysts; namely $47 \mathrm{~kJ}$ $\mathrm{mol}^{-1}$ for a Fe-impregnated pillared saponite clay [31], $56 \mathrm{~kJ} \mathrm{~mol}^{-1}$ for a carbonFe catalysts [19] and $47 \mathrm{~kJ} \mathrm{~mol}^{-1}$ for a Fe/C structured catalyst in a photoassisted process [42]. Therefore, these activation energies are very similar even if a clear meaning to the obtained parameters cannot be attributed under the complex conditions of the chemical process.

Regarding the time required to achieve $50 \%$ of OII degradation, it was found that this transition time significantly decreases when the temperature is increased, with $t^{*}=0.71,0.16,0.09$ and $0.06 \mathrm{~h}$ at $30,45,60$ and $75{ }^{\circ} \mathrm{C}$, respectively (Table 1). In addition, a good correlation was obtained when plotting this parameter versus the temperature in a semi-logarithmic scale (Fig. 11b) that could be used to easily estimate $t^{*}$ at any intermediate temperature.

The apparent kinetic constants $\left(k=1.29,5.83\right.$ and $\left.1.31 \mathrm{~h}^{-1}\right)$ and transition times $\left(t^{*}=2.37,0.71\right.$ and $\left.2.45 \mathrm{~h}\right)$ obtained for the three different initial $\mathrm{pH}$ values represented in Fig. 7 (2, 3 and 4, respectively) confirm that the optimum $\mathrm{pH}$ is 3 , higher or lower $\mathrm{pH}$ values leading to a decrease of the apparent kinetic constant 
(by a factor of ca. 4.5) and an increase in the time required to reach $50 \%$ of the OII degradation (by a factor of ca. 3.4), as also shown in Fig. 11c and d. Therefore, besides the operating temperature, the initial $\mathrm{pH}$ is an important parameter that should be adjusted to 3 , as already proved for the degradation of several organic pollutants with different catalytic materials when using this particular process of treatment $[12,43]$.

Fig. 9 shows the fits to the experimental data for different $\mathrm{H}_{2} \mathrm{O} 2$ concentrations. The effect of $\mathrm{H}_{2} \mathrm{O} 2$ on the degradation process, under the employed range of concentrations tested for this oxidant, seems to be less relevant that the temperature and the initial $\mathrm{pH}$. It is important to be aware that in this particular set of experiments, i.e. for different $\mathrm{H}_{2} \mathrm{O} 2$ concentrations, the lowest determination coefficients (0.9930 and 0.9937) as well as the highest $k \mathrm{CV}$ and $t \mathrm{CV}^{*}(5.9 \%)$ were obtained (Table 1$)$ and, thus, even if some differences between the apparent kinetic constants and the transition times were observed, the results suggest that the effect of this oxidant in the degradation process is not relevant under the range of $\mathrm{H}_{2} \mathrm{O} 2$ concentrations tested.

The fits to the experimental data were very good when the model was used to fit the data obtained for different initial OII concentrations (Fig. 10). It was found that the higher is the initial OII concentration (COII $=0.03,0.10$ and $0.15 \mathrm{mM}$ ), respectively lower is the apparent kinetic constant $\left(k=6.98,5.83\right.$ and $\left.5.11 \mathrm{~h}^{-1}\right)$, represented in a semi-logarithmic scale in Fig. 11e, while the transition time increases $\left(t^{*}=0.52,0.71\right.$ and $\left.0.84 \mathrm{~h}\right)$ nearly exponentially with the initial OII concentration, as represented in Fig. 11f.

The kinetic parameters obtained can be compared with those of other materials, to identify better catalysts (although other criteria should obviously be also taken into account). In a previous study we have fitted this model to the same dye concentration histories, although in slightly different ranges of the experimental variables [29]. For the same operating conditions $\left(30^{\circ} \mathrm{C}, \mathrm{pH} 3, \mathrm{H} 2 \mathrm{O} 2\right.$ dose of 6 $\mathrm{mM}$, and initial OII concentration of $0.1 \mathrm{mM}$ ), the Fe-exchanged $\mathrm{Y}$ zeolite (200 $\mathrm{mg} \mathrm{L} \mathrm{L}^{-1}$ ) yielded an apparent kinetic constant of $5.83 \mathrm{~h}^{-1}$ that is higher - by a factor of 1.9 - than that estimated for a saponite-based catalyst $\left(3.01 \mathrm{~h}^{-1}\right)$ at the same catalyst dose of $200 \mathrm{mg} \mathrm{L}^{-1}$. Additionally, taking into account that the zeolite contains a lower Fe dose ( 5 vs. $16 \mathrm{wt}$.\%), these results point for a higher activity of the Fe-based Y zeolite catalyst when compared with the saponite-based catalyst. So, the material herein developed seems to be truly promising for the envisaged application. 


\section{Conclusions}

A zeolite $\mathrm{Y}$ was used as support for the ion exchange with Fe (5wt.\%) and subsequently employed as catalyst in Orange II degradation by heterogeneous Fenton-like reaction.

Characterization of exchanged zeolite shows that iron is incorporated in the zeolite structure, although a pronounced decrease of the porosity and specific surface area was noticed.

Among all studied variables in the Fenton-like oxidation of the azo dye, the effect of temperature in the process performance is, in the range of conditions tested, the dominant one. The oxidation is accelerated when increasing the temperature from 30 to $75{ }^{\circ} \mathrm{C}$, but $\mathrm{pH}$ plays also an important role; better performance were reached when the initial $\mathrm{pH}$ was set at 3 .

A semi-empirical kinetic model, previously developed for pillared clay catalysts, was successfully validated for the Fe- exchanged Y zeolite. The model, based on the Fermi's equation, describes very well the S-shaped transient conversion histories of the dye, with only 2 fitting parameters. Correlations between these parameters and the experimental conditions were found, which allows easily predicting Orange II concentrations at any time and conditions within the ranges of this study.

Besides, the catalyst exhibits low leaching levels and is more active than others reported in the literature, putting into evidence its potential for this application.

\section{Acknowledgements}

The authors would like to thank: Prof. Carlos Trujillo for providing Zeolite Y; Mr. Ricardo Cortés for assistance in catalysis laboratory; Miss Adriana Rodríguez, Mr. Javier Velandia, Mr. Guillermo Vega, Mr. Oscar Martinez and Mr. Faber Trujillo for assistance in laboratory tests.

\section{References}

[1] United States International Trade Commission, Synthetic organic chemicals United States production and sales, Washington, 1991.

[2] C.M. Carliell, S.J. Barclay, C. Shaw, A.D. Wheatley, C.A. Buckley, Journal of Envi- ronmental Technology 19 (1998) 1133-1137.

[3] D. Méndez-Paz, F. Omil, J.M. Lema, Journal of Water Research 39 (2005) 771-778. 
[4] J. Oakes, P. Gratton, Journal of the Chemical Society Perkin Transactions 2 (1998) 1857-1864.

[5] P.K. Malik, S.K. Saha, Separation and Purification Technology 31 (2003) 241-250.

[6] K. Swaminathan, S. Sandhya, A.C. Sophia, K. Pachhade, Y.V. Subrahmanyam, Chemosphere 50 (2003) 619-625.

[7] K. Dutta, S. Mukhopadhyay, S. Bhattacharjee, B. Chaudhuri, Journal of Haz- ardous Materials 84 (2001) 57-71.

[8] [8] S.H. Lin, C.C. Lo, Water Research 31 (1997) 2050-2056.

[9] R.J. Bigda, Chemical Engineering Progress 91 (1995) 62-67.

[10] C. Walling, Accounts of Chemical Research 8 (1975) 125-131.

${ }_{[11]}$ G. Centi, S. Perathoner, T. Torre, M.G. Verduna, Catalysis Today 55 (2000) 61-69.

[12] J.H. Ramirez, C.A. Costa, L.M. Madeira, G. Mata, M.A. Vicente, M.L. RojasCervantes, A.J. López-Peinado, R.M. Martín-Aranda, Applied Catalysis B: Environmental 71 (2007) 44-56.

[13] M. Neamtu, C. Zaharia, C. Catrinescu, A. Yediler, M. Macoveanu, A. Kettrup, Applied Catalysis B: Environmental 48 (2004) 287-294.

[14] F. Duarte, L.M. Madeira, Separation Science and Technology 45 (2010) 1512-1520.

[15] M. Rios-Enriquez, N. Shahin, C. Duran-de-Bazua, J. Lang, E. Oliveros, S.H. Boss- mann, A.M. Braun, Solar Energy 77 (2004) 491-501.

[16] A.M. Amat, A. Arques, S.H. Bossmann, A.M. Braun, S. Gob, M.A. Miranda, E. Oliveros, Chemosphere 57 (2004) 1123-1130.

[17] A.M. Amat, A. Arques, S.H. Bossmann, A.M. Braun, M.A. Miranda, R.F. Vercher, Catalysis Today 101 (2005) 383-388.

[18] T.L.P. Dantas, V.P. Mendonca, H.J. José, A.E. Rodrigues, R.F.P.M. Moreira, Chem-ical Engineering Journal 118 (2006) 77-82.

[19] J.H. Ramirez, F.J. Maldonado-Hódar, A.F. Pérez-Cadenas, C. MorenoCastilla, C.A. Costa, L.M. Madeira, Applied Catalysis B: Environmental 75 (2007) 312-323.

[20] N. Panda, H. Sahoo, S. Mohapatra, Journal of Hazardous Materials 185 (2011) 359-365.

[21] P. Shukla, S. Wang, H. Sun, H.-M. Ang, M. Tadé, Chemical Engineering Journal 164 (2010) 255-260.

[22] J. Feng, X. Hu, P.L. Yue, H.Y. Zhu, G.Q. Lu, Chemical Engineering Science 58 (2003) 679-685.

[23] O.S.N. Sum, J. Feng, X. Hu, P.L. Yue, Chemical Engineering Science 59 (2004) 5269-5275. 
[24] M.N. Timofeeva, S.T. Khankhasaeva, S.V. Badmaeva, A.L. Chuvilin, E.B. Burgina, A.B. Ayupov, V.N. Panchenko, A.V. Kulikova, Applied Catalysis B: Environmental 59 (2005) 243-248.

[25] J. Carriazo, E. Guélou, J. Barrault, J.M. Tatibouët, R. Molina, S. Moreno, Catalysis Today 107-108 (2005) 126-132.

[26] J. Barrault, M. Abdellaoui, C. Bouchoule, A. Mejeste, J.M. Tatibouët, A. Louloudi, N. Papayannakos, N.H. Gangas, Applied Catalysis B: Environmental 27 (2000) L225-L230.

[27] E.V. Parkhomchuk, M.P. Vanina, S. Preis, Catalysis Communications 9 (2008) 381-385.

[28] M. Noorjahan, V.D. Kumari, M. Subrahmanyam, L. Panda, Applied Catalysis B: Environmental 57 (2005) 291-298.

[29] J.H. Ramirez, A.M.T. Silva, M.A. Vicente, C.A. Costa, L.M. Madeira, Applied Catal- ysis B: Environmental 101 (2011) 197-205.

[30] J.A. Ostos Ortiz, Synthesis and characterization of a zeolite (Y) modified by ionic exchange and impregnation with platinum, Thesis of Bachelor Science, Department of Chemistry, National University of Colombia, 1994.

[31] J.H. Ramirez, M. Lampinen, M.A. Vicente, C.A. Costa, L.M. Madeira, Industrial \& Engineering Chemistry Research 47 (2008) 284-294.

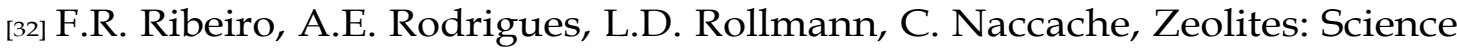
and Technology, NATO ASI Series, M. Nijhoff Publishers, The Hague, 1984. [33] M. Guisnet, J.P. Gilson, Zeolites for Cleaner Technologies, Imperial College Press, London, 2002.

${ }_{[34]}$ J. Cejka, J. Heyrovsky, Studies in Surface Science and Catalysis, Elsevier, Ams- terdam, 2005.

[35] T.R. uda, P. Dutta, Environmental Science and Technology 39 (2005) 61476152.

${ }_{[36]}$ E. Fach, W.J. Waldman, M. Williams, J. Long, R.K. Meister, P.K. Dutta, Environ- mental Health Perspectives 110 (2002) 1087-1096.

[37] A. Auroux, S. Kaliaguine, Microporous Materials 5 (1995)17-27.

[38] J. Feng, X. Hu, P.L. Yue, Water Research 40 (2006) 641-646.

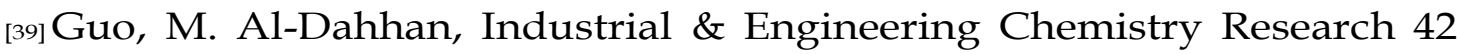
(2003) 2450-2460.

[40] A. Pintar, J. Levec, Journal of Catalysis 135 (1992) 345-357.

[41] T. Gordon, A. Marsh, Catalysis Letters 132 (2009) 349-354.

${ }_{[42]}$ T. Yuranova, O. Enea, E. Mielczarski, J. Mielczarski, P. Albers, J. Kiwi, Applied Catalysis B: Environmental 49 (2004) 39-50.

[43] J.H. Ramírez, L.M. Madeira, in: A. Gil, S.A. Korili, R. Trujillano, M.A. Vicente (Eds.), Pillared Clays and Related Catalysts, first ed., Springer, New York, USA, 
2010, pp. 129-165. 


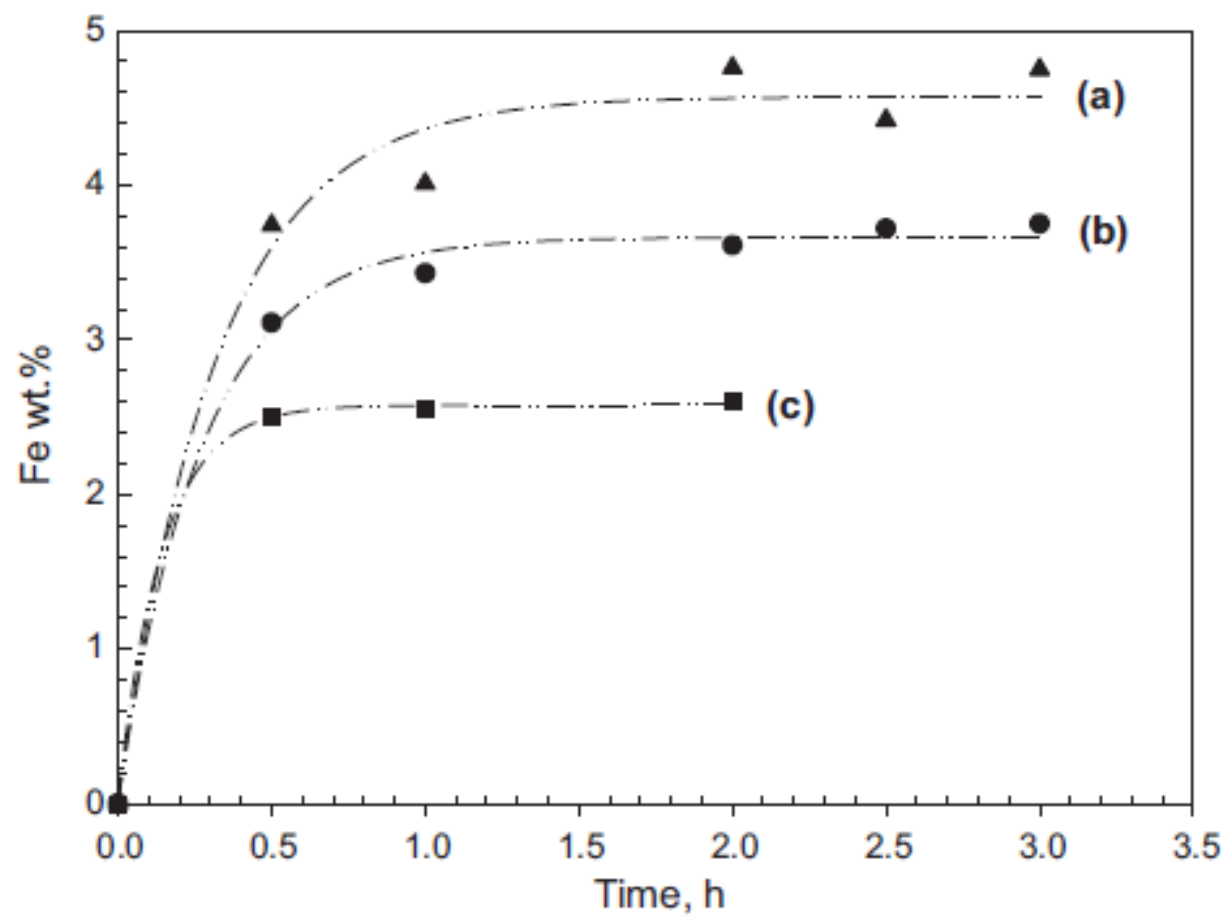

Fig. 1. Iron content of exchanged zeolite as a function of time for different atomic ratios of $\mathrm{Fe} / \mathrm{Na}$ : (a) ratio $=4,(\mathrm{~b})$ ratio $=2,(\mathrm{c})$ ratio $=1$.

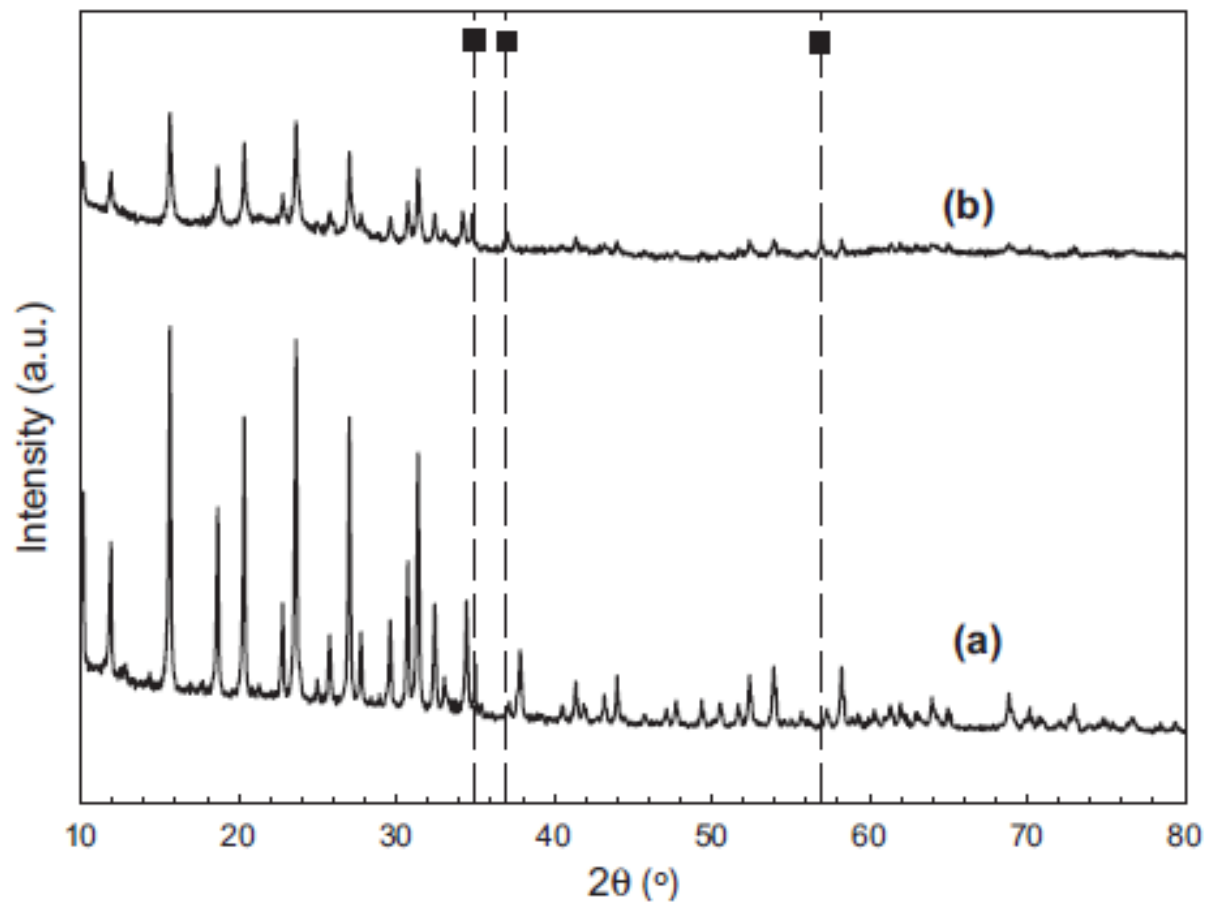

Fig. 2. XRD profiles of (a) non-exchanged zeolite, and (b) exchanged zeolite with $\mathrm{Fe} / \mathrm{Na}=4$, at. ( $\cdot \mathrm{Fe} 2 \mathrm{O} 3)$. 


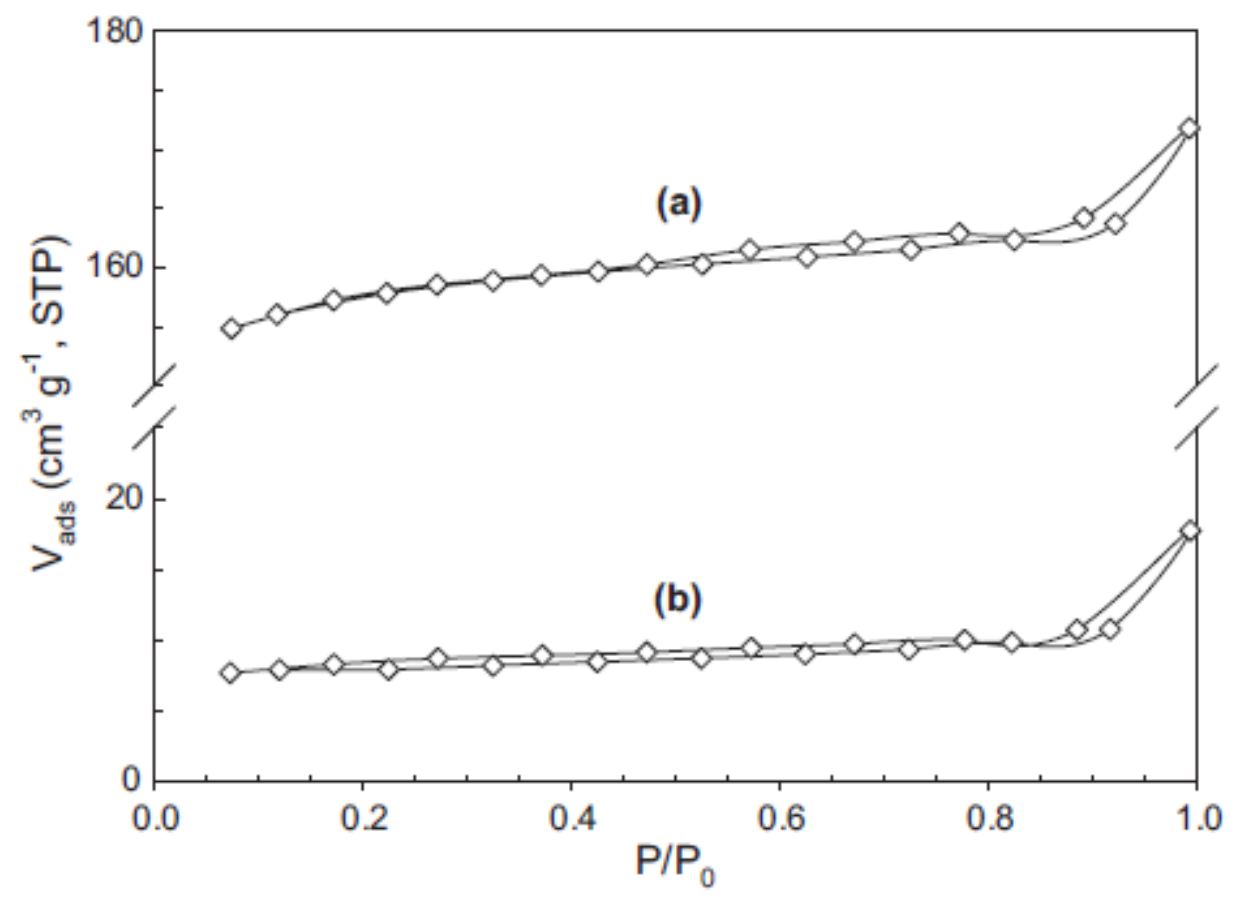

Fig. 3. N2 adsorption isotherm of (a) non-exchanged zeolite, and (b) exchanged zeolite.

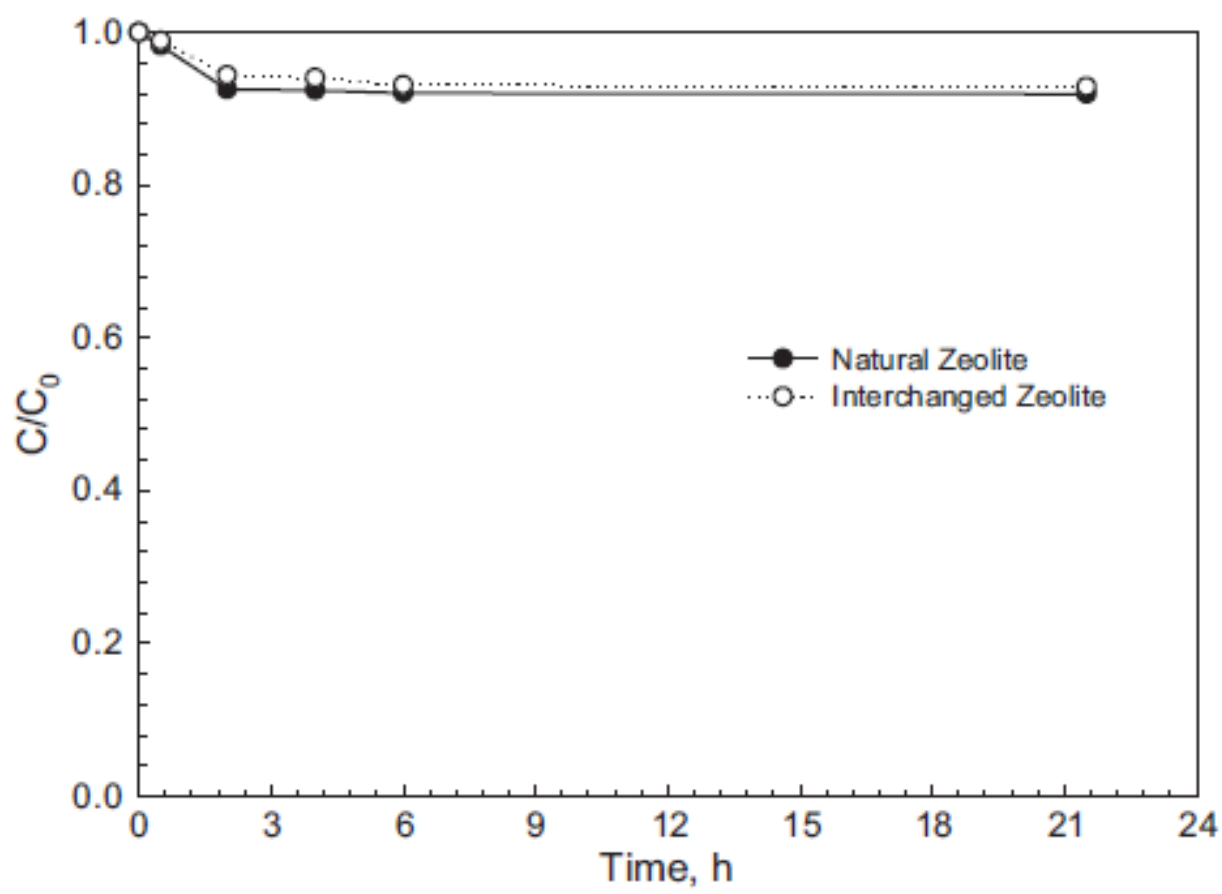

Fig. 4. Dye removal by adsorption with the unchanged or ion-exchanged zeolite with $\mathrm{Fe} / \mathrm{Na}=4$, at. $\left(\mathrm{COII}=0.1 \mathrm{mM}, T=30{ }^{\circ} \mathrm{C}, \mathrm{pH} 3.0, C\right.$ solid $=200 \mathrm{mg}$ $\left.\mathrm{L}^{-1}\right)$. 


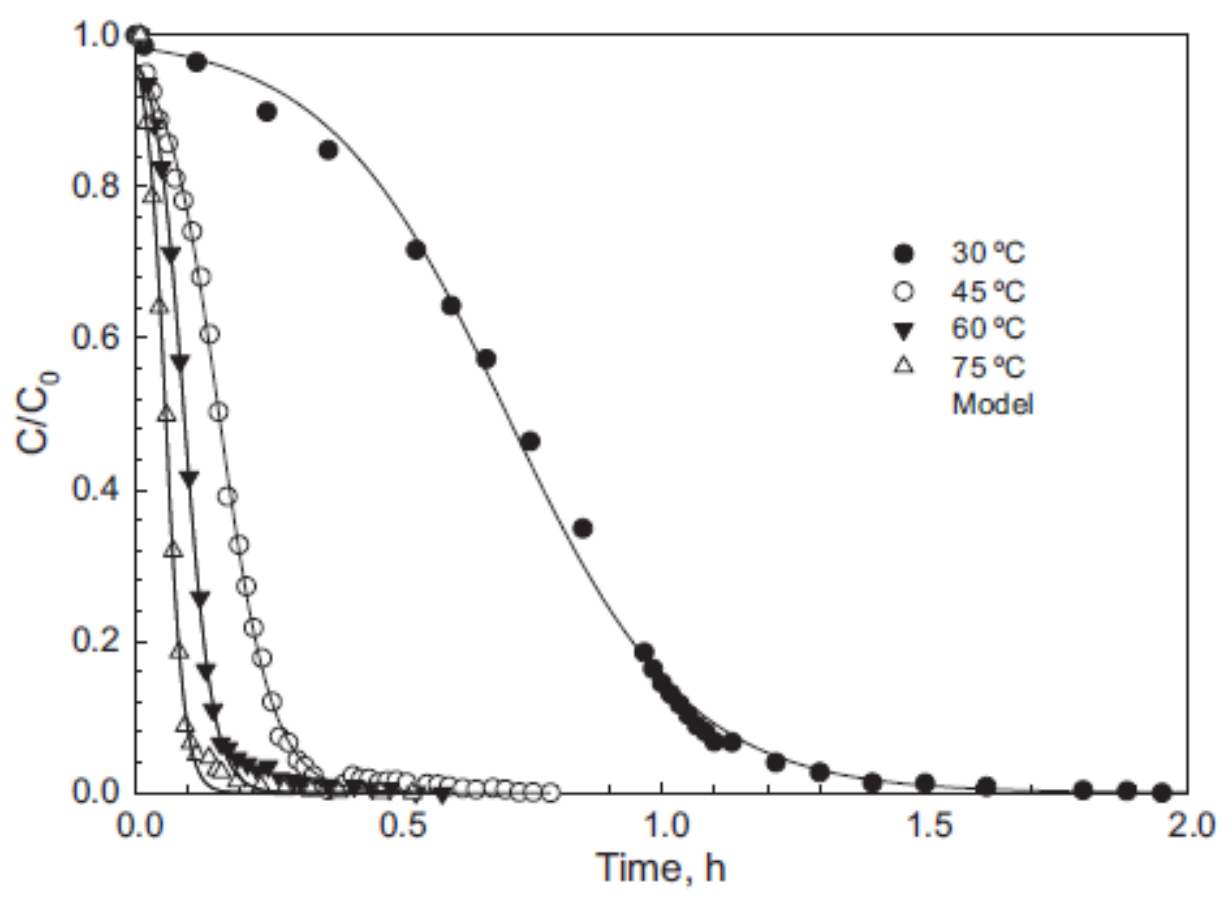

Fig. 5. Effect of temperature on the dye degradation histories $(\mathrm{CH} 2 \mathrm{O} 2=6$ $\mathrm{mM}$, COII- $0.1 \mathrm{mM}$, initial $\mathrm{pH} 3$ ). The lines represent the fitting by the model (Eq. (3) with data reported in Table 1).

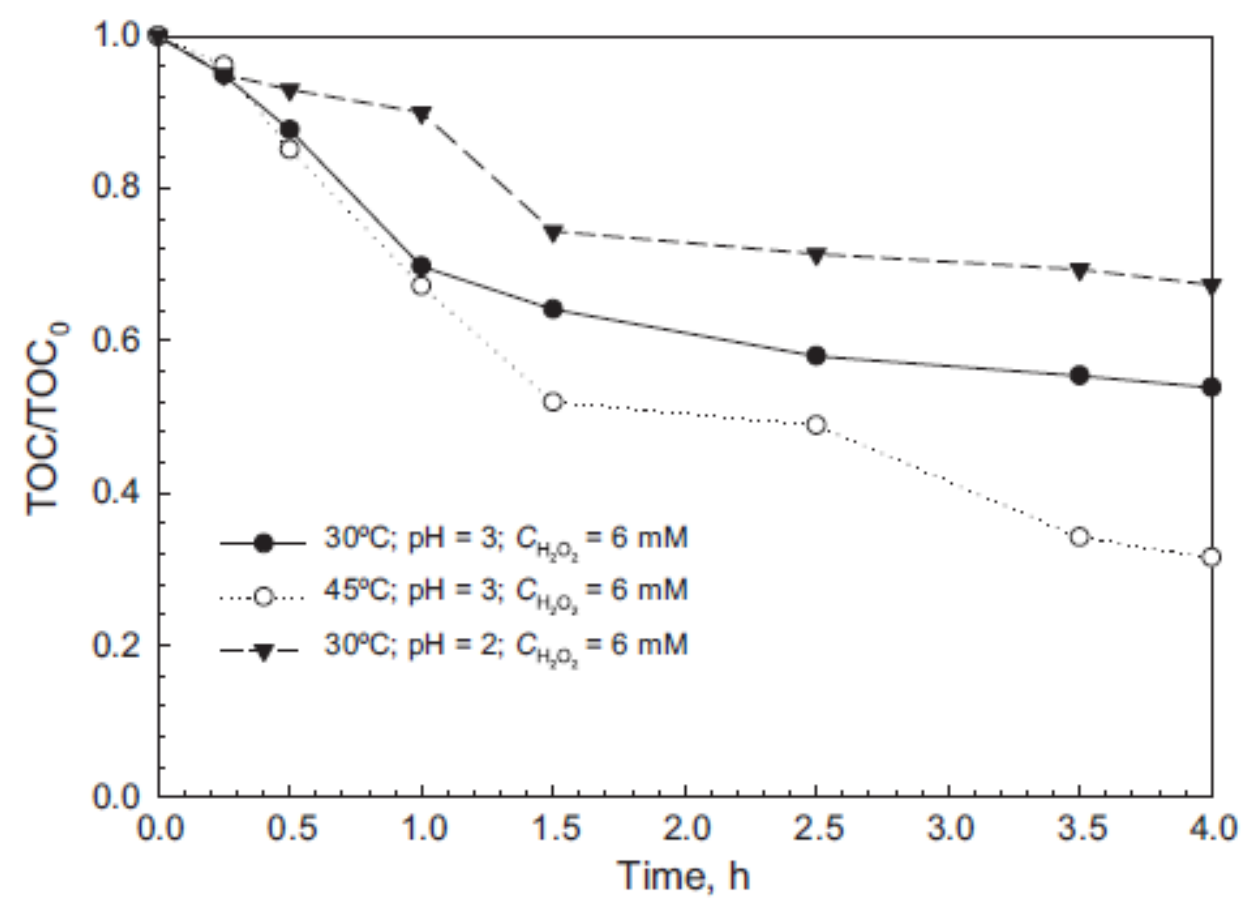

Fig. 6. Effect of temperature and $\mathrm{pH}$ on TOC removal $\left(\mathrm{CH}_{2} \mathrm{O}_{2}=6 \mathrm{mM}\right.$, COII $=0.1 \mathrm{mM})$. 


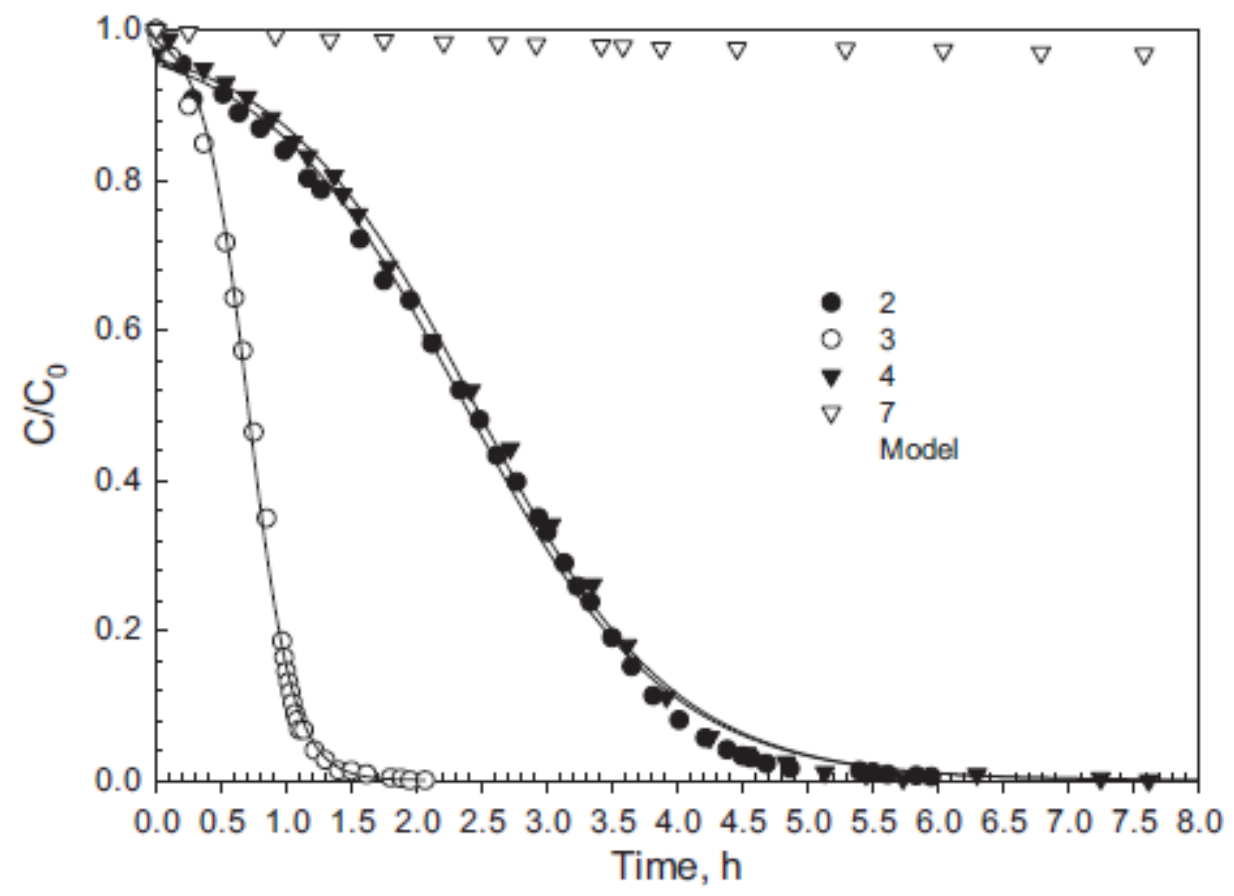

Fig. 7. Effect of the initial $\mathrm{pH}$ on the dye degradation histories $\left(T=30^{\circ} \mathrm{C}\right.$, $\left.\mathrm{CH}_{2} \mathrm{O}_{2}=6 \mathrm{mM}, \mathrm{COII}=0.1 \mathrm{mM}\right)$. The lines represent the fitting by the model (Eq. (3) with data reported in Table 1).

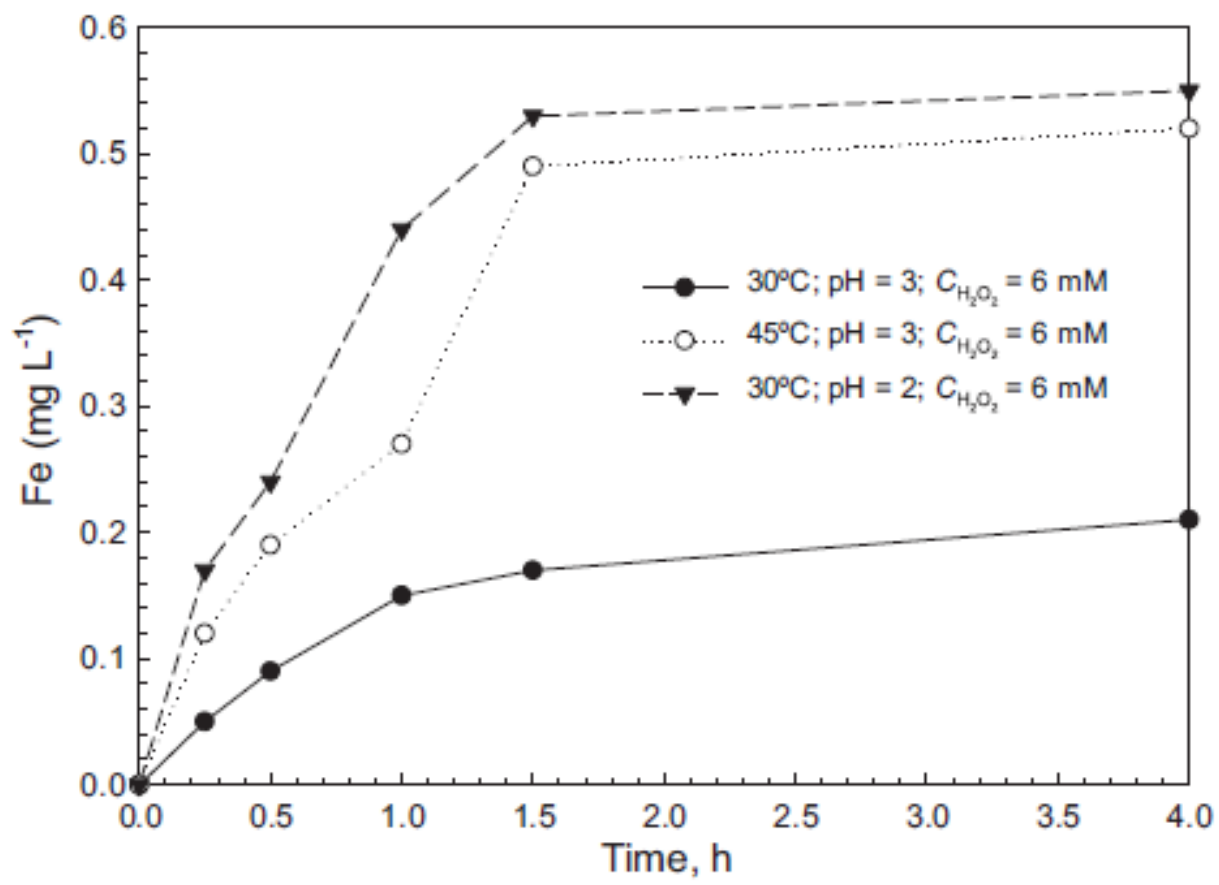

Fig. 8. Effect of the temperature and initial $\mathrm{pH}$ on the iron leaching $(\mathrm{CH} 2$ $\mathrm{O} 2=6 \mathrm{mM}$, COII $=0.1 \mathrm{mM})$. 


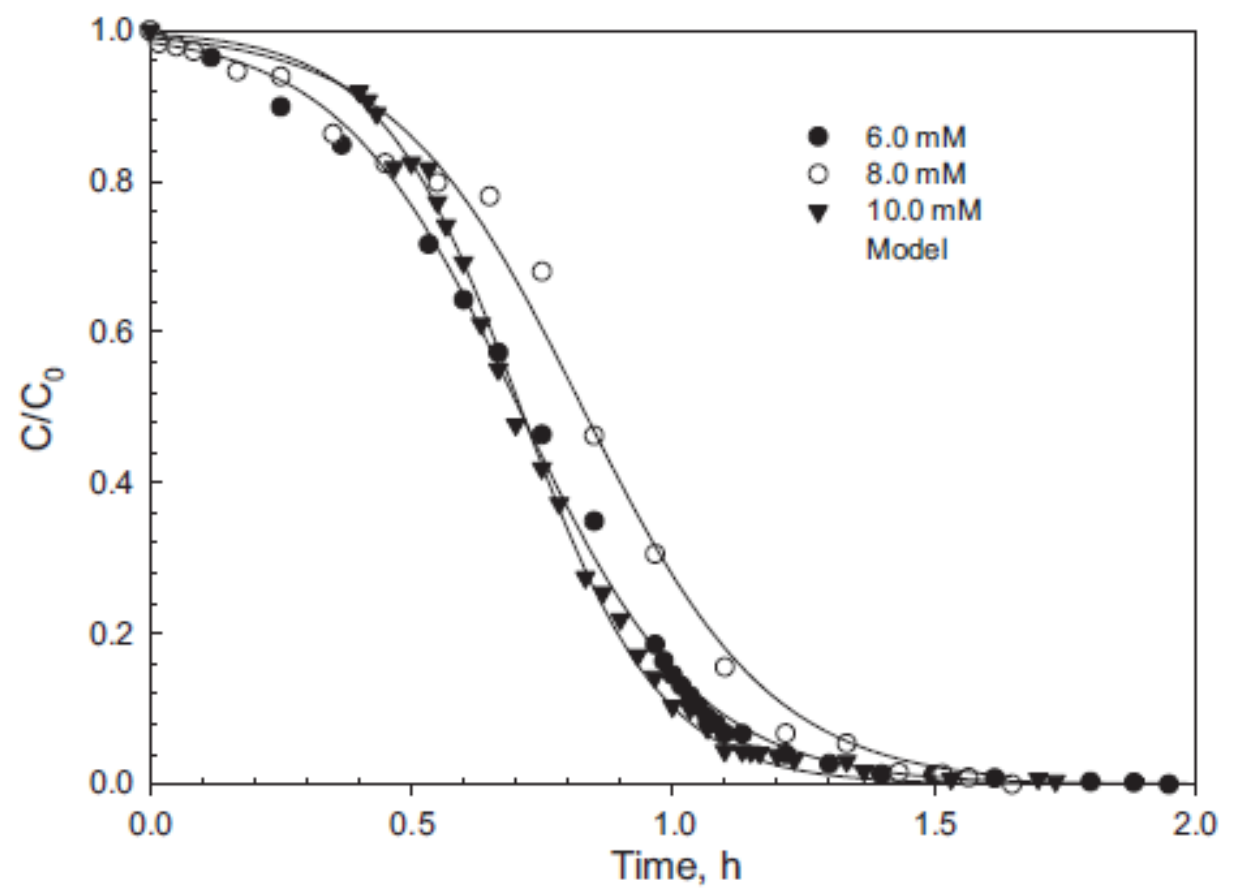

Fig. 9. Effect of the initial hydrogen peroxide concentration on the dye degradation histories $\left(T=30^{\circ} \mathrm{C}, \mathrm{COII}=0.1 \mathrm{mM}\right.$, initial $\left.\mathrm{pH} 3\right)$. The lines represent the fitting by the model (Eq. (3) with data reported in Table 1).

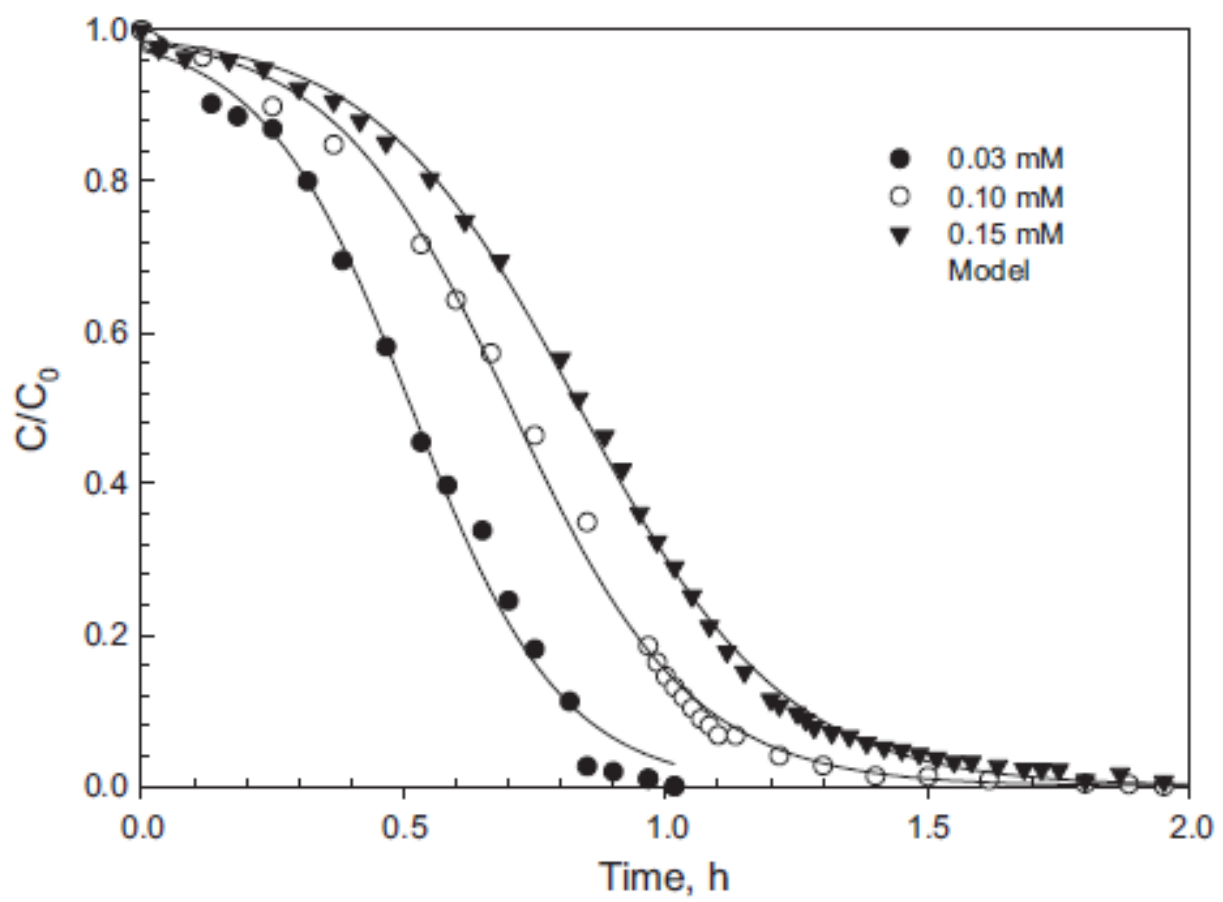

Fig. 10. Effect of the initial dye concentration on the degradation histories ( $T$ $=30^{\circ} \mathrm{C}, \mathrm{CH}_{2} \mathrm{O}_{2}=6 \mathrm{mM}$, initial $\left.\mathrm{pH} 3\right)$. The lines represent the fitting by the model (Eq. (3) with data reported in Table 1). 

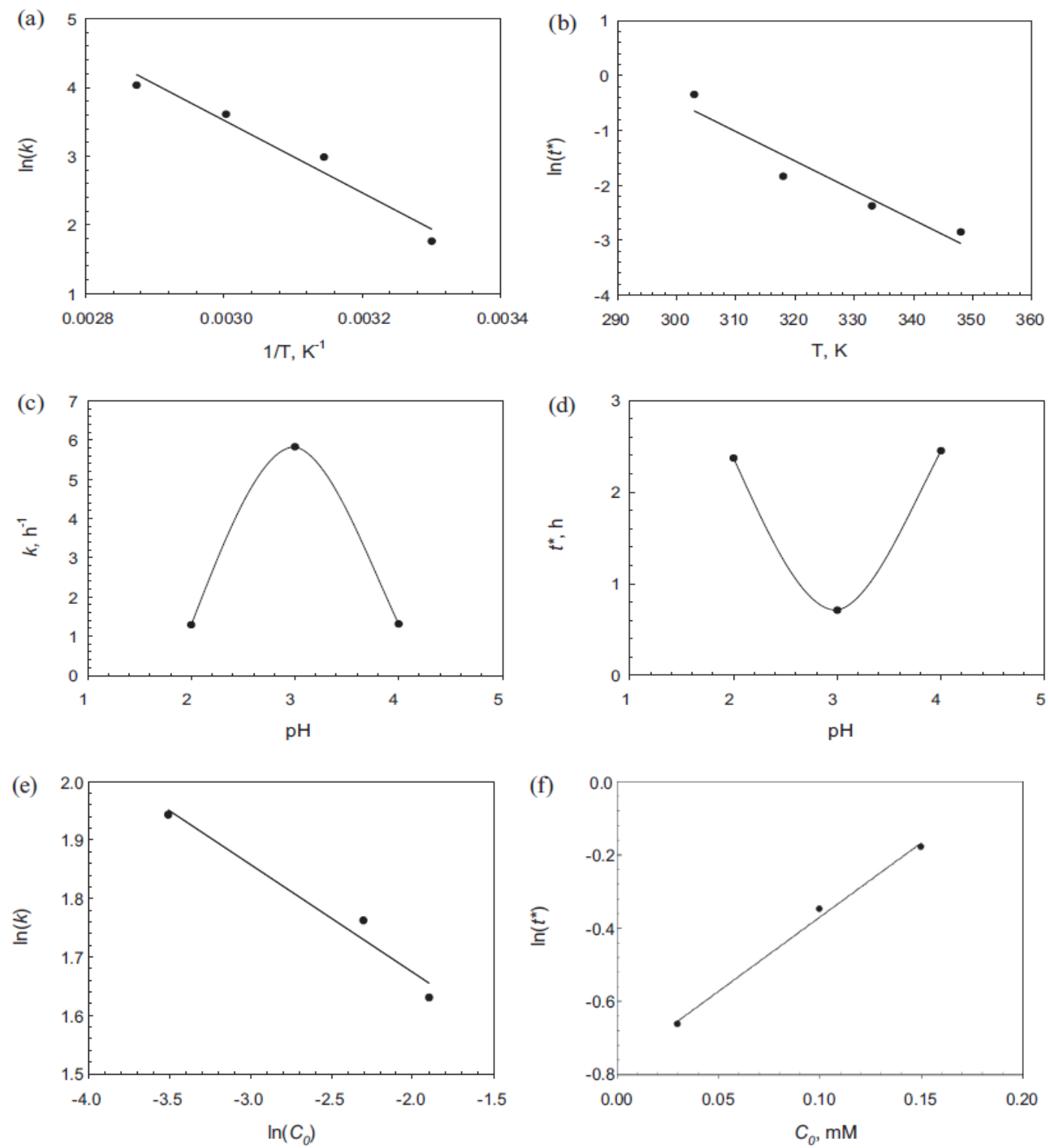

Fig. 11. Arrhenius plot for the apparent rate constant of the model (a) and effect of temperature on the transition time (b); the lines represent the linear regression fittings. Effect of the $\mathrm{pH}$ on the rate constant of the model (c) and on the transition time (d). Effect of the initial dye concentration on the rate constant of the model (e) and on the transition time (f); the lines represent the linear regression fittings. For the other conditions please refer to Table 1. 
Table 1

Conditions employed in the runs performed, and kinetic parameters obtained after regression using Eq. (3) (CCat $=200 \mathrm{mg}$ $\mathrm{L}^{-1}$ ). (Bold parameters in a column means a set of experiments performed varying the respective parameter while keeping the others constant.).

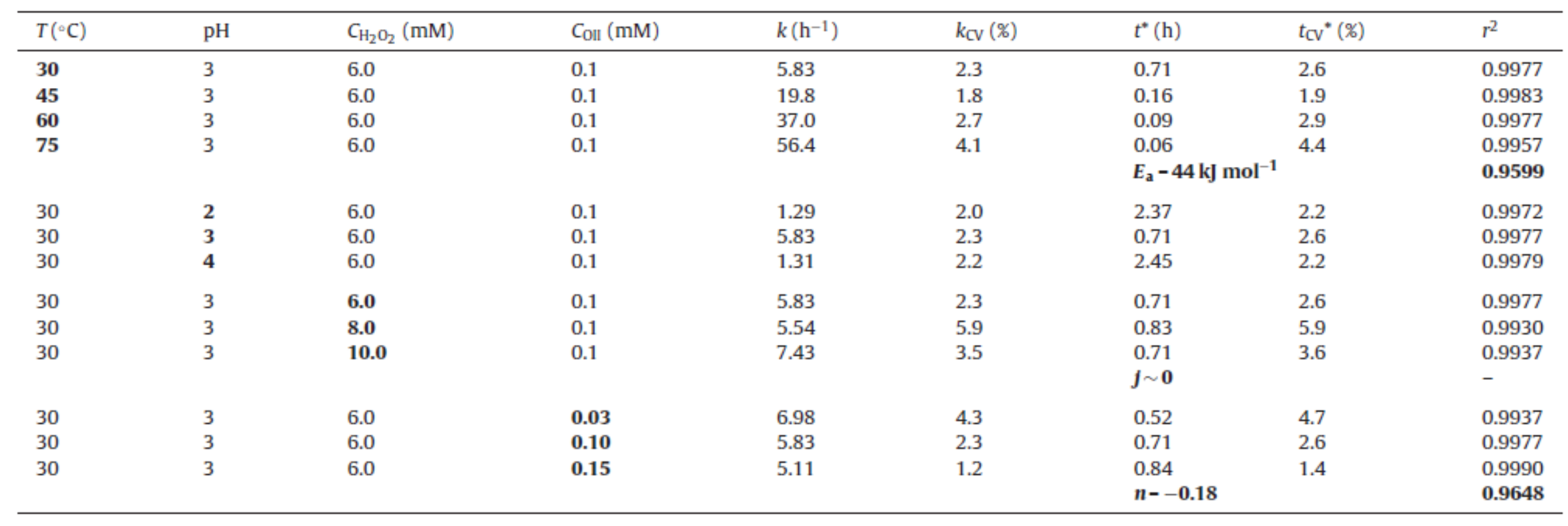


Table 2

XRF results for exchanged and non-exchanged zeolites.

\begin{tabular}{lll}
\hline Element/compound & \multicolumn{2}{l}{ Weight percentage (\%) } \\
\cline { 2 - 3 } & Non-exchanged zeolite & $\begin{array}{l}\text { Exchanged zeolite } \\
\text { (Fe/Na-4, at.) }\end{array}$ \\
\hline $\mathrm{SiO}_{2}$ & 74.55 & 70.21 \\
$\mathrm{Al}_{2} \mathrm{O}_{3}$ & 21.63 & 18.88 \\
$\mathrm{Fe}_{2} \mathrm{O}_{3}$ & - & 7.85 \\
$\mathrm{Na}_{2} \mathrm{O}$ & 3.71 & 2.13 \\
$\mathrm{MgO}$ & - & 0.50 \\
$\mathrm{Co}$ & - & 0.03 \\
$\mathrm{CaO}$ & 0.04 & 0.03 \\
$\mathrm{Cl}$ & 0.04 & 0.37 \\
$\mathrm{~K}$ & 0.02 & - \\
$\mathrm{TiO}$ & - & - \\
$\mathrm{S}$ & 0.01 & - \\
$\mathrm{Zn}$ & 0.002 & - \\
$\mathrm{Zr}$ & 0.002 & - \\
\hline
\end{tabular}

